\title{
Mollusc fisheries and length-weight relationship in Tonle Sap flood pulse system, Cambodia
}

\author{
Peng Bun Ngor ${ }^{1,2, *, \dagger}$, Ratha Sor ${ }^{2,3, \dagger}$, Leang Hour Prak ${ }^{1}$, Nam So ${ }^{4}$, Zeb S. Hogan ${ }^{5}$ and Sovan Lek ${ }^{2}$ \\ ${ }^{1}$ Fisheries Administration, No. 186, Preah Norodom Blvd., Khan Chamcar Morn, PO Box 582, Phnom Penh, Cambodia \\ 2 CNRS, Université Toulouse III Paul Sabatier, ENFA, UMR5174 EDB (Laboratoire Évolution and Diversité Biologique), 118 route de \\ Narbonne, 31062 Toulouse, France \\ ${ }^{3}$ Relations and Cooperation Office - Chea Sim University of Kamchaymear, No. 157, Preah Norodom Blvd, Khan Chamkarmon, \\ Phnom Penh, Cambodia \\ ${ }^{4}$ Mekong River Commission, Vientiane, Lao PDR \\ ${ }^{5}$ Department of Biology, University of Nevada, 1664 N. Virginia Street, Reno, NV 89557, USA
}

Received: 13 May 2018; Accepted: 20 September 2018

\begin{abstract}
Molluscs are important for ecological function, livelihoods and fisheries, but are often forgotten in research and management. Here, we investigated intra-annual variation in the landing and growth patterns of three mollusc species, i.e., Corbicula moreletiana, Pila virescens and Pila ampullacea, using one-year daily data on landing catches and values, recorded in Kampong Chhnang province of Tonle Sap (TS) Lake. Overall, 8330 tonnes with a first sale landing value of US\$ 1.4 million for the three species were reported. Also, we found that $C$. moreletiana was abundant during the dry season with high temperature and less precipitation. By contrast, the two Pila species were abundant from the early rainy to early dry seasons when precipitation and water levels increase. The length-weight relationship analysis indicated that a faster growth in weight of Pila species occurred in the rainy season, and a general negative allometric growth was observed for the three species. This implies that their populations were intensively fished. Our preliminary results suggest that molluscs in the TS Lake (i) are important resources in support of people's livelihoods, (ii) respond differently to intra-annual variation in temperature, precipitation and hydrology and (iii) are being intensively exploited with significant reduction in growth rate. Therefore, it is necessary to conduct further comprehensive research describing status of mollusc stocks and their ecology to support long-term management and conservation of this important aquatic fauna. Our study contributes to establishing the first important baseline data and information on key mollusc species for the TS.
\end{abstract}

Keywords: snail and bivalve / catch and value / Corbicula moreletiana / Pila virescens / Pila ampullacea

\section{Introduction}

Molluscs are one among the four most diverse groups of invertebrates in freshwater ecosystems (Balian et al., 2008). Freshwater molluscs are divided into two main groups: the Bivalvia and Gastropoda (Sangpradub and Boonsoong, 2006). Over 5000 species are estimated worldwide, representing $4 \%$ of the total freshwater faunal diversity (Balian et al., 2008). Moreover, freshwater molluscs have a high variation in life history strategies and complex ecological interactions, and inhabit a wide range of habitats such as rivers, lakes, streams, swamps, ponds and rice fields (Köhler et al., 2012).

\footnotetext{
*Corresponding author: pengbun.ngor@gmail.com

$\dagger$ Co-first author; these authors contributed equally to this work.
}

The Lower Mekong Basin (Fig. 1) is known as a rich biodiversity hotspot for molluscs and other aquatic fauna (MRC, 2003; Sodhi et al., 2004; Strong et al., 2008). This basin supports $\sim 121$ species of gastropods and $\sim 39$ species of bivalves (Davis, 1988). Amongst these species, at least 111 gastropods and 5 bivalves are endemic to the basin (Davis, 1981). This great diversity is due to the tropical monsoon rainfall system, which is characterized by regular dry (November-April) and rainy (May-October) seasons, and to the extensive floodplains as well as broad tributaries of the Lower Mekong Basin. The largest floodplain of the Lower Mekong Basin is the Tonle Sap (TS) Lake, which is also the biggest freshwater wetland in Southeast Asia (Sarkkula et al., 2003; Adamson et al., 2009). In the TS Lake and River system, molluscs are the second largest fishery after fishes (Rainboth, 1996). They are widely abundant, for centuries, around the 


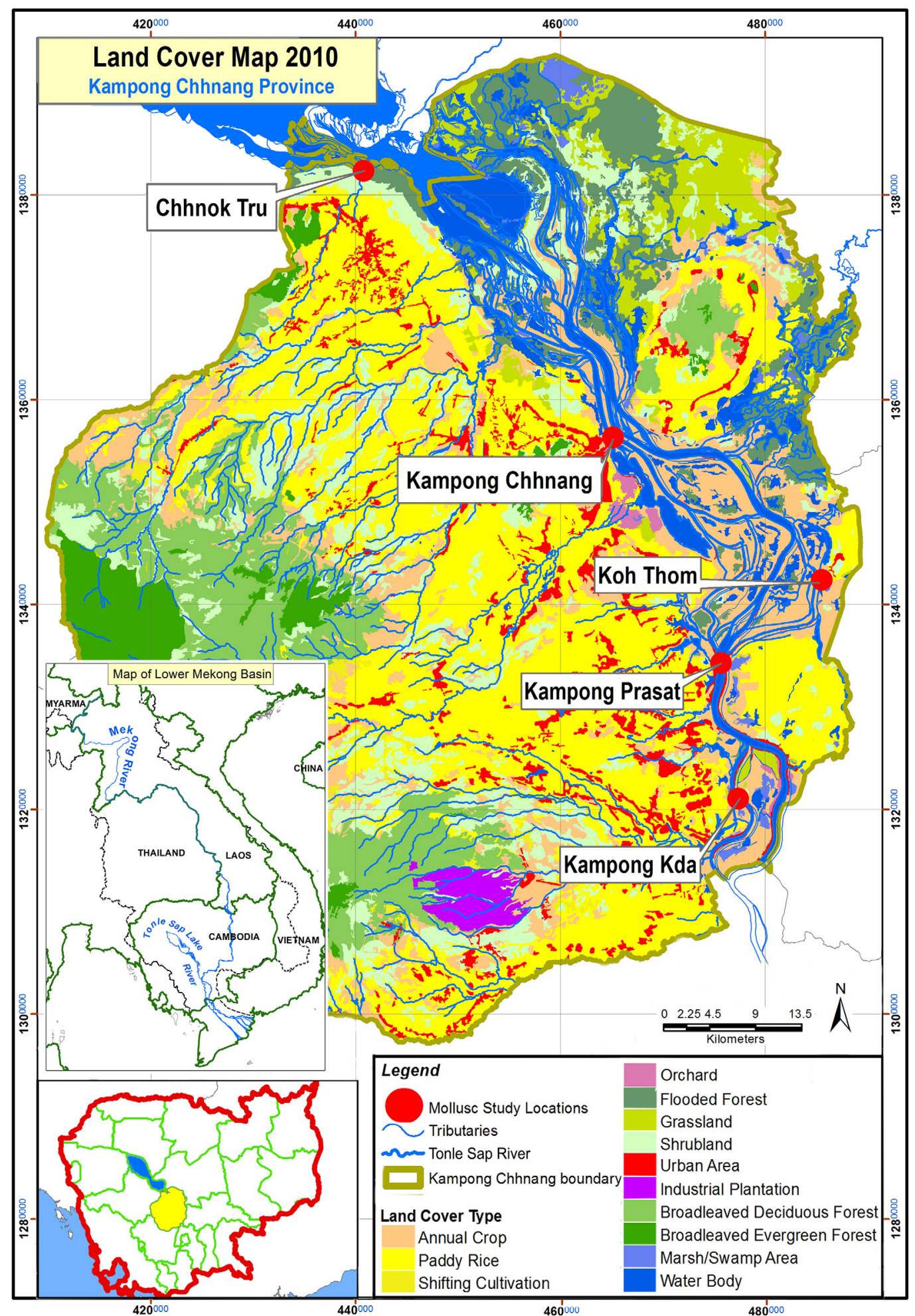

Fig. 1. Map showing major mollusc-landing sites covered in the study and land cover in Kampong Chhnang province, Cambodia (modified from Ngor et al., 2016).

TS Lake (Zhou, 2002), and their biomass is exceptionally high compared to other zoobenthos (Chea et al., 2016).

In the TS Lake, bivalves (e.g., Asian clam Corbicula spp.) are reported to be abundant during the dry season (MRC, 2003), while the gastropods (e.g., apple snails Pila spp.) are numerous during the rainy season and in the beginning of the dry season when floodwaters recede and the temperature reaches its minimum of the year (MRC, 2003). Despite the high estimated mollusc diversity and production in the TS Lake, little attention has been paid to the study of mollusc 
fisheries regarding landing catches, values and other aspects of the mollusc stocks, i.e., length-weight relationship. This leads to the ignorance of the importance of molluscs in support of both food security and ecology, e.g., when discussing about the impacts of water development or aquatic faunal management and conservation issues.

The lack of focus on mollusc fisheries is a concern as they functionally contribute to enhancing food availability and security, providing physical structures for other aquatic organisms (Gutiérrez et al., 2003; Halwart, 2006; Vaughn et al., 2008) and removing particulate organic matters from water columns (Sousa et al., 2008; Musig et al., 2012). Furthermore, molluscs provide a source of protein intake and income for local people in some developing countries, e.g., Cambodia, Laos, Thailand and Vietnam, that share the Lower Mekong Basin (Coates et al., 2003; Köhler et al., 2012). Subsequently, changes in their abundances and biomass can directly or indirectly influence ecosystem functioning and the livelihoods of local people.

Biomass and production of molluscs are closely linked to their morphological characteristics, e.g., body length and weight (Froese, 2006). Analyses of these characteristics, i.e., length-weight relationship (LWR), are useful for informing the management of the stocks (e.g., stock assessment) and are important to determine individual and population conditions (Hilborn and Waiters, 1992; Simon et al., 2014). Moreover, the analyses of LWR of molluscs can also provide an indication of environmental conditions in which they inhabit because their maturity stages are affected by surrounding environmental variables, e.g., hydrology, food availability, water quality and temperature (Simon et al., 2014; Saleky et al., 2016).

In this study, we aimed to (1) investigate intra-annual variation (i.e., on a daily and monthly basis) in landing catches of three mollusc species: C. moreletiana (Cyrenidae), Pila virescens and Pila ampullacea (Ampullariidae), (2) examine the relationship between the monthly landing catches and key environmental variables and (3) describe the LWR of the three species based on observed monthly length-weight data. Due to high variation in water levels, precipitation and temperature, which all influence molluscs' body development (Simon et al., 2014; Saleky et al., 2016), we expected that the monthly growth patterns of the three species significantly change within the year. This study is an expansion of a previous study by Ngor et al. (2016), who reported the total landing catches and values of five key mollusc species in Kampong Chhnang province. Based on this paper, we further investigate the details of the three abovementioned species (out of the five species recorded in Ngor et al., 2016) that form the largest mollusc landing in Kampong Chhnang province of the TS River and Lake.

\section{Materials and methods}

\subsection{Study area}

The study area is located in Kampong Chhnang province, covering a surface area of $5521 \mathrm{~km}^{2}$ (NIS, 2013), of which $\sim 48 \%$ is attributed to rice paddy and annual crop production, $\sim 24 \%$ to shrubland and broad-leaved deciduous forest and $12 \%$ to water body and flooded forest (Fig. 1). The rest of the land cover is made up of broad-leaved evergreen forests $(\sim 6 \%)$, urban $(\sim 5 \%)$, grassland and swamp area $(\sim 3 \%)$, shifting cultivation $(0.8 \%)$, industrial plantation $(0.8 \%)$ and orchard $(0.3 \%)$ (Fig. 1).

Kampong Chhnang province is considered as a transition zone, linking the TS Lake with the TS River, the river with a flow-reversal system. The TS River plays an important role in bringing the excess water from the Mekong River to the TS Lake during the rainy season, and in draining the water from the TS Lake back to the Mekong River during the dry season when the rain ceases and water levels in the Mekong drop (Kummu et al., 2014). As such, most of the area in this province is covered with fertile land (alluvial plain) and is almost an ever-wet heart of Cambodia. This condition is naturally suitable for a diverse aquatic fauna to inhabit and for local people to closely engage with agricultural productions including fisheries. About $87 \%$ of population are primarily involved in agricultural activities including rice farming, crop gardening, fishing and livestock (NCDD, 2010).

Our study covers five major commercial mollusc landing sites in Kampong Chhnang province in the TS floodplains, i.e., Kampong Kda, Kampong Prasat, Koh Thom, Kampong Chhnang and Chhnok Tru (Fig. 1). Data collected from these sites roughly represented the annual mollusc landings (for the three study species) in the province.

\subsection{Hydrology}

The hydrological cycle in Kampong Chhnang province is strongly influenced by seasonal variability of the Mekong floods. During the flooding season (May-October) when higher water levels occur in the Mekong, the water in the TS River flows into the TS Lake. In the dry season (NovemberApril), the TS River reverses its flow direction from the TS Lake to the Mekong River. Based on a 12-year record (2000 2012), the lowest water levels take place in April (mean: $2.5 \mathrm{~m}$ ) and peak in October (mean: $10.3 \mathrm{~m}$ ). During this period, the lowest water was $2.02 \mathrm{~m}$ in 2006 and the highest was $11.8 \mathrm{~m}$ in 2011. See Supplementary Information Figure S1 for the intraannual variability of the 12-year daily water levels in the TS River at Kampong Chhnang hydrological station.

\subsection{Data collection}

Daily data of the three species were recorded from commercial traders at the five commercial landing sites that were determined by focus group discussions with Kampong Chhnang Fisheries Administration Cantonment (Provincial level), Fisheries Administration Section (District level) and Fisheries Administration Unit (Commune level). Technical details about fishing gears and collection methods of molluscs are described in Deap et al. (2003: 84-86). Five field research officers participated in the daily field-data collection process; each was based at one of the five commercial landing sites over the period from 1 February 2014 to 31 January 2015. Prior to field data collection, data recording forms and a checklist of ecological questions were prepared to record daily catches, prices and weight-length data and collect ecological information on the study species in each site. The field research officers were then trained how to (i) fill in the data collection forms, (ii) take samples and subsamples for estimating the total landings of molluscs by species, e.g., when large landings of snail 
Table 1. Total landings $(\mathrm{kg})$ of the three mollusc species and their correspondent first sale landing values (US\$) from February 2014 to January 2015 .

\begin{tabular}{lllll}
\hline Species & Total landing $(\mathrm{kg})$ & Mean daily landing $(\mathrm{kg})$ & Total value $(\mathrm{US} \$)^{*}$ & Mean daily value $(\mathrm{US} \$)$ \\
\hline C. moreletiana & $6,436,439$ & $23,900( \pm 14,660)$ & 369,805 & $1,375( \pm 1,028)$ \\
$P$. virescens & $1,511,280$ & $4,140( \pm 2,437)$ & 781,025 & $2,140( \pm 1,399)$ \\
$P$. ampullacea & 381,899 & $1,046( \pm 2,267)$ & 218,053 & $598( \pm 1,423)$ \\
\hline
\end{tabular}

* At the time of sampling, the average exchange rate was about Cambodian Riel 4000 to US\$1.00.

species were not sorted, (iii) identify key mollusc species and (iv) measure the weight-length of the individual mollusc species. Mollusc identification was based on the Mekong River Commission's (MRC) guide: "Identification of Freshwater Invertebrates of the Mekong River and Its Tributaries" (Sangpradub and Boonsoong, 2006) and applesnail.net at each landing site. It is noted that $P$. virescens in this study is the accepted scientific name of Pila polita in the MRC identification guide and at applesnail.net and in Ngor et al. (2016). For photos, length measurement and identification keys of mollusc species presented in this study, see Supplementary Information Table S1.

A $100-\mathrm{kg}$ scale, accurate to $100 \mathrm{~g}$, was used to weigh the molluscs landing at each site. The collected daily landing catches (by species) from each site were then aggregated to obtain the overall daily and monthly landings for the entire province. Correspondingly, daily landing prices by species per kilogram at each site was also recorded for calculating the overall daily mollusc landing values by species for the province. Additionally, length-weight data at each landing site were recorded using a $1-\mathrm{kg}$ electronic scale and a caliper accurate to $1 \mathrm{~g}$ and $1 \mathrm{~mm}$, respectively. Mollusc maximum body size (height) was applied for the length measurement. As much as possible, at least 30 individuals of each study species from sub-daily landings within each month were randomly selected for the height measurement, and all collected individuals were analyzed in this study. The sample size of C. moreletiana was small, compared to the Pila species, as the species was mainly landed in Chhnok Tru. In the case of small landing (i.e., $<30$ individuals), all samples were used for the measurement. The scales and calipers were calibrated before use. The descriptive statistics on monthly length and weight of the study species are provided in Supplementary Information Table S2.

Daily water levels at the hydrological station of Kampong Chhnang (latitude: 12.25053; longitude: 105.6859) were registered by the Mekong River Commission (MRC, 2010). In addition, we included the monthly temperature and precipitation, which were obtained from bioclimatic data (http://www.worldclim.org), for further analysis.

\subsection{Statistical analysis}

To investigate daily and monthly variations in the mollusc landing catches (i.e., the catch of each species in $\mathrm{kg}$ ), the package "ggplot2" of R was used to plot the catches against time. The differences in monthly landing catches were tested using a one-way ANOVA (when residuals of the models were normal: Shapiro-Wilk test, $p>0.05$, and homoscedasticity:
Bartlett's test, $p>0.05$ ), or otherwise the non-parametric test (Kruskal-Wallis) was used.

The nonmetric multidimensional scaling (NMDS) and the function "envfit" from "vegan" package were applied to associate the monthly mollusc landing catches with the recorded water levels and the monthly precipitation and temperature. The function "ordispider" of R was employed to visualize the monthly variability of mollusc catches on the NMDS ordination plot. In the NMDS analysis, missing values were not accepted and thus were removed to enable the analysis. Therefore, only data from February to May 2014 and from September 2014 to January 2015 (for the three mollusc species and environmental variables) were used for the analysis. Every test for significant differences, $p$ values $<0.05$ were considered. We performed all analyses in the $\mathrm{R}$ language program (R Development Core Team, 2017).

The length-weight relationship (LWR) of each species was expressed by an exponential equation $W=a L^{\mathrm{b}}$, where $W$ is the body weight $(\mathrm{g})$ and $L$ is the total length $(\mathrm{mm})$. This equation can be linearized as $\log W=\log a+b \log L$, where $a$ is the intercept and $b$ is the slope (regression coefficient), which is used to indicate the growth patterns, i.e., isometric $(b=3)$ or positive allometric $(b>3)$ or negative allometric $(b<3)$. The LWR of each species was computed on a monthly basis in order to increase the sample size, and thus improve the reliability of the analysis of the LWR.

\section{Results}

\subsection{Overall landings and economic values}

C. moreletiana was the most abundant species as it formed the largest landings of all species recorded with a total landing of $6,436,439 \mathrm{~kg}$ across the study period. $P$. virescens ranked second with the total landing of $1,511,280 \mathrm{~kg}$, and $P$. ampullacea was the least abundant among the three species with the total landings of $381,899 \mathrm{~kg}$. The species that provided the highest total landing values (based on the first sale landing prices) was $P$. virescens, followed by $C$. moreletiana and P. ampullacea (Tab. 1).

\subsection{Intra-annual variation in mollusc landings and their association with environmental variables}

The daily landings of the three species were highly varied within the observed complete hydrological cycle (Fig. 2). The highest landing catch of $C$. moreletiana occurred from February to April 2014 and from December 2014 to January 2015 , covering almost the entire dry season. Its lowest landing 


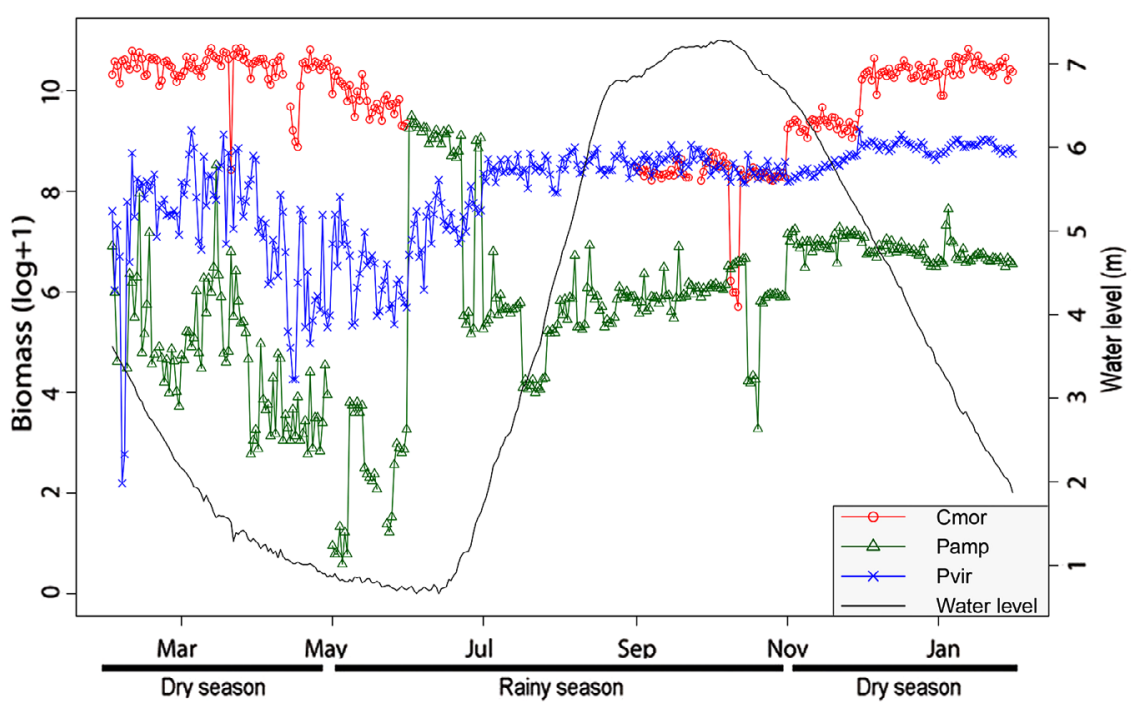

Fig. 2. The variation in landing catches of Corbicula moreletiana (Cmor), P. ampullacea (Pamp), P. virescens (Pvir) over a complete hydrological cycle from February 2014 to January 2015.

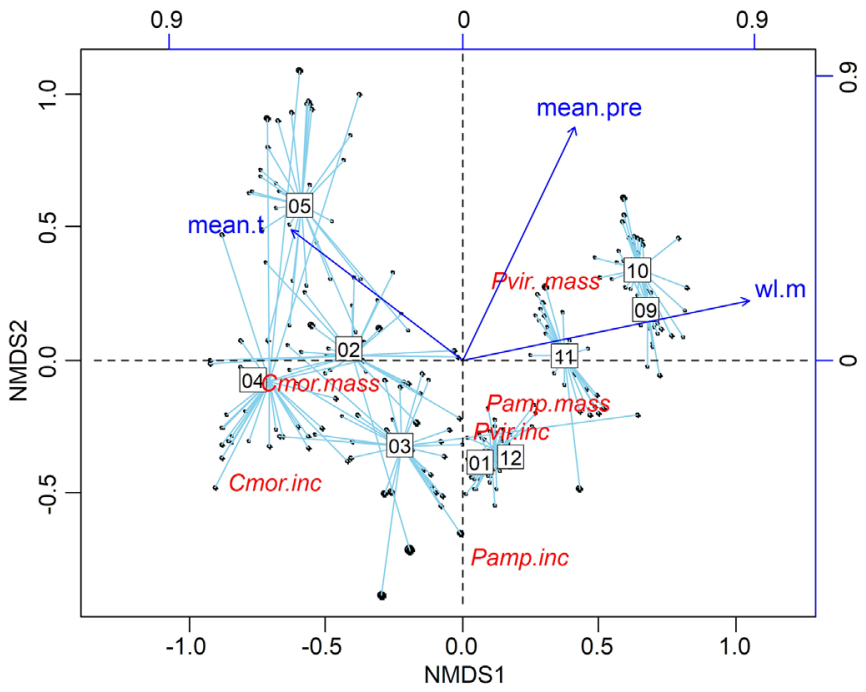

Fig. 3. The NMDS ordination of all samples based on Bray-Curtis dissimilarity matrix of monthly landing catches and vectors of Corbicula moreletiana (Cmor), P. ampullacea (Pamp) and $P$. virescens (Pvir) and their recorded landing values. The monthly mean temperature (mean.t), precipitation (mean.pre) and water levels (wl.m) were fitted using the envfit function on the NMDS ordination map. mass and inc denote the catches and values of each species, respectively. The two-digit number represents each month of the year, i.e., $01=$ January etc.

was observed between September and October 2014 during the high flow period. For $P$. virescens and $P$. ampullacea, relatively high landings were recorded from June 2014 to January 2015, partly during the increasing water levels (inflow) between June and October, and partly during the falling water levels when TS River resumes its normal flow direction (outflow); whereas decreased landing catches were observed from February to May 2014 during the low flow period (Fig. 2).
The daily landing values of each species was found to be autocorrelated with the daily landing catches (see Supplementary Information Fig. S2).

The monthly variation in the landing catches within the year was significant for each species: $C$. moreletiana (ANOVA, $F=426, p<0.001), P$. ampullacea $(F=284$, $p<0.001)$ and $P$. virescens $(F=306, p<0.001)$ (Fig. 3). The relationship between each species' monthly catches and the analysed variables is shown in Figure 3. The bivalve C. moreletiana that was mostly abundant from February to May was positively correlated to the monthly mean temperature of the year and negatively correlated to the water levels. The NMDS ordination map clearly showed contrasting patterns between the bivalve and the two gastropod species. The bivalve $C$. moreletiana that was mostly abundant from February to May was positively correlated to the monthly mean temperature of the year and negatively correlated to the water levels; whereas $P$. ampullacea and $P$. virescens, mostly abundant from September to November, were positively associated with the water levels and negatively associated with the monthly mean temperature. $P$. virescens was a unique species linked to the high precipitation.

\subsection{Length-weight relationships}

The monthly LWRs estimated for each species were significant and strongly explained by the linear regression models with relatively high values of the coefficients of determination $\left(R^{2}\right)$ (Tab. 2). The regression coefficients $b$ were mostly lower than 3 , except for the $b$ value of $P$. ampullacea in October. The $b$ values of $C$. moreletiana in the dry season (April, November and December) were slightly higher than they were in the rainy season (May, September and October). Interestingly, opposite findings were observed for the Pila species where the $b$ values were found to be higher in the rainy season (May-October) than they were in the dry season (November-April). 
Table 2. Monthly length-weight relationships (LWR) for each study species.

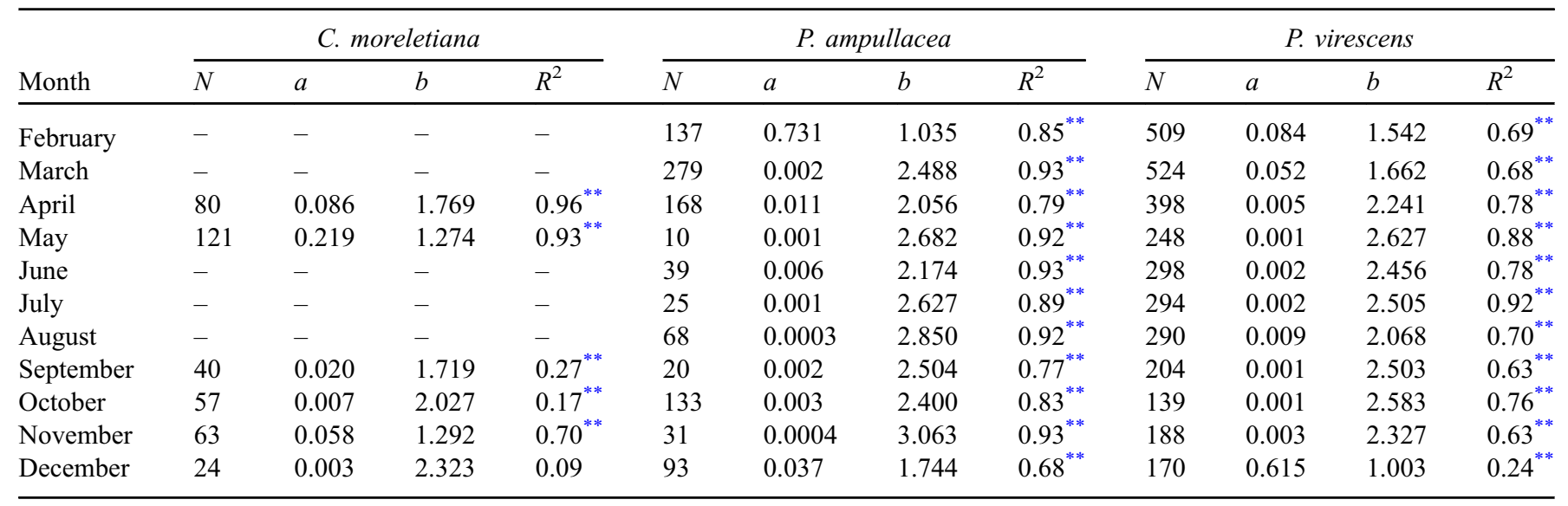

** $p<0.01, N$ : number of individuals, $a$ : intercept, $b$ : slope, $R^{2}$ : coefficient of determination.

\section{Discussion}

\subsection{Mollusc fisheries and economic values}

We found substantial daily harvests of three mollusc species from the TS Lake. C. moreletiana was the most abundant species, making up the highest catches over the study period. The great abundance of this species may reflect the widespread ability and diverse reproductive strategies of its genus, ranging from free-swimming larvae to incubation of larvae in gills (Vaughn and Hakenkamp, 2001; Glaubrecht et al., 2006). Therefore, they can reach their optimal number when suitable habitat conditions are available. For the Pila species, their numerous abundance could be attributed to their ability to tolerate water deficiency and to be capable of prolonged periods of aestivation in the soil during the dry season (Köhler et al., 2012; Hayes et al., 2015). According to Köhler et al. (2012), ampullariids are ubiquitous and reproduced rapidly, which makes them widespread, abundant and easy to collect by the locals, as well as resilient to high collection pressure.

In the Lower Mekong Basin, at least seven mollusc species are known to be abundant and are harvested at considerable levels. These species include $P$. scutata, $P$. virescens and $P$. ampullacea (Ampullariidae), Mekongia swainsoni and Filopaludina martensi cambodiensis (Viviparidae) and $C$. fluminea and C. moreletiana (Cyrenidae) (Claridge, 1996; Ngor et al., 2014, 2016). Local people of the Lower Mekong Basin exploit molluscs for food and trade on a daily basis (Campbell and Parnrong, 2001; Ngor et al., 2014). In Cambodia, however, up to 10 bivalve and 12 gastropod species are exploited (Lim, 1995). These species contribute significantly to the daily, monthly and annual yields of other aquatic animals (OAAs) (Halwart, 2006; Ngor et al., 2014). For example, an estimation of 121,000 tonnes of the annual yield of OAAs, which mainly comprised molluscs, crustaceans, amphibians and reptiles, was reported in Cambodia for the year 2008 (MRC, 2010). From the annual yield of OAAs, Cambodian people are known to consume $9.2 \mathrm{~kg} /$ person/year (Hortle, 2007), of which $3.5 \mathrm{~kg}$ are molluscs (MRC, 2010). This suggests that OAAs including the three species belonging to Ampullariidae and Cyrenidae are an important source of food nutrition, security and part of income generation for the local people.

We found that, over the year of the survey, some 8330 tonnes of mollusc landings for the three study species were reported from the five major landing sites in Kampong Chhnang province, with the corresponding total first sale value recorded at around US\$ 1.4 million. Our results provided strong evidence and strengthened the results of previous studies that mollusc fisheries are among the important sources of employment and income generation as well as food security in the region. For example, poor households in many Cambodian provinces (e.g., Kampong Cham, Kampot, Kratie, Battambang and Kampong Thom) earn some $60-70 \%$ of their daily income from OAAs, of which molluses contribute a large quantity (Persson et al., 2010; RUPP, 2010). The harvested molluscs can be sold to traders with the first sale value earned by each local family between US\$ 90-180 (MRC, 2003). Specifically, of all reported OAAs collected from the rice field in Battambang province in nine 25-ha study sites of TS Lake over the 7-month period from August 2003 to February 2004, molluscs made up of $\sim 10 \%$ of the total economic value, which was about US\$22,912 (Hortle et al., 2008). In general, local people living in Cambodia and countries sharing the Lower Mekong Basin earn their daily income from selling the excess harvest of OAAs, particularly mollusc species (e.g., $P$. virescens and $P$. ampullacea) which have high economic values (MRC, 2003).

\subsection{Relationship between landing catches and water levels, temperature and precipitation}

Our results demonstrated that the landing catches of the bivalve species were positively correlated to temperature. This finding supports a previous survey in Kampong Cham province that a high harvest of bivalve species mainly took place during the dry season (MRC, 2003), which is comparatively hot. High temperatures provide good conditions for increases in phytoplankton abundance (Vannote et al., 1980; Statzner and Higler, 1985; Hecky and Kilham, 1988), which in turn enhances the abundance of phytoplankton 
feeders (e.g., Corbicula spp.) (Vaughn and Hakenkamp, 2001). Moreover, a high nutrient load (when the water recedes and therefore nutrients are concentrated) also supports a high abundance of Corbicula spp. (Vanderploeg et al., 1995; Vaughn and Hakenkamp, 2001; Sor et al., 2017). Bogan (2008) also reported that a dense aggregation of bivalves was observed in the period of high temperature and when large quantities of algae, diatoms, bacteria, fine particulate and organic particles were present. These combined factors therefore likely explain the high production of bivalves that we found during the dry season.

A contrasting result was found for the gastropod species; the landing catches of $P$. virescens and $P$. ampullacea were positively associated with precipitation and water levels, and negatively associated with temperature. During the dry season, these snails are able to withstand water shortage and hot weather by aestivating (Köhler et al., 2012; Hayes et al., 2015), and hence are not collected in large numbers. During the rainy season, water levels in the TS Lake is highly influenced by floods from the upstream Mekong. A large area of Kampong Chhnang province which is connected to the TS Lake is usually flooded, covering the belt of flooded forests, degraded forests and wetlands surrounding the lake and river (Lieng et al., 1995; Poulsen et al., 2002; Ngor et al., 2018a). These conditions enable the snail species to gain access to breeding and nursing grounds for reproduction and growth, and therefore drive their enormous production during the rainy season. In addition, the rains may increase the abundance of food sources (e.g., aquatic plants), as the snails, being ampullariids, are primarily macroherbivorous (Strong et al., 2008).

Our findings also support previous studies conducted in the tropics and in some temperate areas. In the Lower Mekong Basin and in Indian Gho-Manhasan stream, Cyrenidae (e.g., C. cashmeriensis) were mostly found in dry season when high temperatures were observed (IUCN, 2013; Sharma et al., 2013). Similarly, they have been found to occur abundantly between summer and autumn, which is the warmest period of the year (Pigneur et al., 2014). For Pila species, they can be found in both dry and rainy seasons, e.g., for the case of P. scutata found in Indonesia (Priawandiputra et al., 2017) and of $P$. globosa found in Bangladesh (Huq et al., 2002). To the best of our understanding, however, there appear to be no clear seasonal changes in the abundance found for the Pila species from other regions, except for the case of our present study in the TS Lake.

\subsection{Length-weight relationships}

Our study, using the length-weight data by month, found that there was a general negative allometric growth for the three study species, as reflected by low $b$ values (i.e., $<3$ ). For C. moreletiana, although there were higher $b$ values found in the dry season, due to nutrient accumulation that supports their growth (Vanderploeg et al., 1995; Vaughn and Hakenkamp, 2001), the $b$ values were still lower than 3 . This was also observed for $P$. virescens and $P$. ampullacea in most cases. However, in contrast to C. moreletiana, higher $b$ values of the two gastropod species were found in the rainy season. As explained earlier, this could be due to suitable habitat conditions, e.g., more available space due to increasing water levels and food availability - water plants and other vegetation - which can better support their growth. The same analysis on daily measurements confirmed the similar findings with regards to the growth patterns for the three study species (see Supplementary Information Fig. S3). Overall, although a negative allometric growth was generally observed for each species, our results suggest that the growth in weight of the two gastropod species is faster during the rainy season than during the dry season. At the same time, there is little evidence of seasonal growth patterns of the bivalve species due to insufficient data.

The LWR is commonly used as an indicator of biological fisheries, changes in individual and population status and growth patterns of organisms (Gayon, 2000; Gaspar et al., 2001; Albuquerque et al., 2009). We found that the weight gain in each study species is slower than the growth in length, as inferred from low $b$ values. This clearly indicates that the collected molluscs were young individuals, and their populations, in particular the bivalve, were not able to reach their mature stage before being harvested. Thus, our findings may imply that the three species were intensively fished and were being overharvested.

\subsection{Conclusion and management implications}

Many studies recognize the importance of molluscs' contribution to food security, employment and economy, especially for the poorer segments of the society (Balian et al., 2008; Strong et al., 2008; Köhler et al., 2012). This recognition becomes obvious when fish is less abundant and molluscs become an important alternative resource to support rural families' livelihoods. Our study recorded 8330 tonnes corresponding to US\$1.4 million of the first sale value from the three mollusc species landed in one of the six provinces around the TS Lake. In Cambodia, in addition to local consumption, mollusc species are also exported to neighbouring countries such as Vietnam and China. Among the three study species, the two Pila species are commercially exported, due to their higher economic values, compared to C. moreletania. However, in terms of yield, the C. moreletania was by far the highest. Our current assessment on mollusc landings in Kampong Chhnang was likely still underestimated because our study covered only major commercial landing sites. There are also numerous smallscale mollusc collectors that are dispersed in space and time in the complex inland ecosystems of the TS Lake. Also, the estimated mollusc landings excluded the quantity that collectors keep for household consumption.

Habitat degradation and fragmentation resulting from flood-forest clearing and wastes from intensive rice farming and industrial crops in the TS Lake, threats from golden apple snail (Pomacea canaliculata), intense harvesting pressure and the ignorance from formal institutions have put the important resources in a precarious condition. Overharvesting of mollusc species, e.g., as reflected by the negative allometric growth, may also enhance the abundance and spread of the invasive, noncommercial golden apple snail, due to less competition with indigenous snail species and available space. The increase of this invasive snail is, on the one hand, a threat to the highvalue native snail species, and on the other hand, is a harmful species to the agricultural productivity because it mainly feeds on young seedling of rice species and other aquatic-dependent 
crops (Ngor et al., 2014). Furthermore, the changes in the status of Corbicula species can alter local and regional ecosystem functioning. Corbicula species provide a key ecosystem service in fresh waters by filtering out large quantities of algae, diatoms, bacteria, organic particles and silt and absorbing heavy metals and large organic molecules (Bogan, 2008; Musig et al., 2012). Moreover, both the bivalves and gastropods play the pivotal role in the food web dynamics, e.g., being one of the main food sources for many threatened, endemic and economic species inhabiting the Mekong and TS Lake including fish (e.g., Probarbus jullieni, Chitala blanci, Cyclocheilichthys enoplos, Helicophagus waandersii, Pangasius bocourti), turtle (e.g., Sacalia quadriocellata), birds (e.g., Larus ridibundus, Anhinga melanogaster) (Rainboth, 1996; Poulsen et al., 2004; Ministry of Agriculture Forestry and Fisheries [MAFF], 2007; Froese and Pauly, 2017) water snakes and mammals, e.g., rats (applesnail.net; Brooks et al., 2007). Overharvesting of any particular mollusc species is thus likely to adversely influence not only local people but also the ecological functioning and food web of the TS ecosystem and beyond.

Given the current status of indiscriminate fishing effects of the TS (McCann et al., 2016; Ngor et al., 2018b) and human actions, e.g., hydropower developments that block fish migration routes, modify river flows and degrade habitats as well as the decline of flooded forests around the TS Lake (MRC, 2011), the seasonal catches of many fish species are declining. The declines in fish populations have led to a strong shift in the natural resources exploitation to other aquatic animals, e.g., molluscs, water snakes, crustaceans - shrimps in the TS River and Lake. During our field data collection, we observed that these resources were being intensively exploited. Therefore, it is imperative to call for more research, legislative support with appropriate planning, management and conservation actions if such important resources are to be sustained for the ecosystem and for long-term support to the people's livelihoods.

\section{Supplementary Material}

Supplementary figures and tables.

The Supplementary Material is available at https://www. limnology-journal.org/10.1051/limn/2018026/olm.

Acknowledgments. We are grateful to a USAID-supported project: Wonders of the Mekong that provides funding support to PBN and ZSH. This research is also in part funded by the Erasmus Mundus LOTUS projects (European Commission) and the Belmont Forum (TLSCC project) to R.S. Cordial thanks to the Fisheries Programme of the Mekong River Commission (MRC) for making available the mollusc datasets used in this study. Special thanks to the Fisheries Administration of Cambodia, particularly Mr. Kimchhea Chhuon, who helped facilitate the data collection process. Sincere thanks to our research officers from the Kampong Chhnang Fisheries Administration who assisted in recording daily landings of molluscs. Finally, Laboratory of Evolution and Biological Diversity (EDB) was supported by "Investissement d'Avenir" grants CEBA, Ref. ANR-10-LABX-0025; TULIP, Ref. ANR10-LABX-41).

\section{References}

Adamson PT, Rutherfurd ID, Peel MC, Conlan IA. 2009. The hydrology of the Mekong River. In: Campbell IC, ed. The Mekong Biophysical Environment of an International River Basin. Amsterdam: Elsevier Inc., pp. 53-76.

Albuquerque F, Peso-Aguiar M, Assunção-Albuquerque M., Gálvez L. 2009. Do climate variables and human density affect Achatina fulica (Bowditch) (Gastropoda: Pulmonata) shell length, total weight and condition factor? Braz J Biol 69: 879-885.

Balian EV, Segers H, Lévèque C, Martens K. 2008. The freshwater animal diversity assessment: an overview of the results. Hydrobiologia 595: 627-637.

Bogan AE. 2008. Global diversity of freshwater mussels (Mollusca, Bivalvia) in freshwater. Hydrobiologia 595: 139-147.

Brooks SE, Reynolds JD, Allison EA, Touch B. 2007. The Exploitation of Homalopsid Water Snakes at Tonlé Sap Lake, Cambodia Homalopsine Snakes: Evolutionary Experiments in Terrestrial-Aquatic Transitions. Melbourne, Florida: Krieger Publishing, pp. 31-37.

Campbell IC, Parnrong S. 2001. Limnology in Thailand: present status and future needs. In: Williams W, ed. 27th Congress of the International-Association-of-Theoretical-and-Applied-Limnology, Dublin, Ireland: E. Schweizerbart'sche Verlagsbuchhandlung, pp. 2135-2141.

Chea R, Guo C, Grenouillet G, Lek S. 2016. Toward an ecological understanding of a flood-pulse system lake in a tropical ecosystem: food web structure and ecosystem health. Ecol Modell 323: 1-11.

Claridge G. 1996. An Inventory of Wetlands of the Lao P.D.R. Bangkok: IUCN - The World Conservation Union in collaboration with UNEP Environment Assessment Programme for Asia and the Pacific.

Coates D, Ouch P, Suntornratana U, Nguyen TT, Viravong S. 2003. Biodiversity and Fisheries in the Mekong River Basin, Mekong Development Series No. 2, Phnom Penh, Cambodia: Mekong River Commission.

Davis GM. 1981. The origin and evolution of the gastropod family Pomatiopsidae, with emphasis in the Mekong River Triculinae. Syst Zool 30: 115-118.

Davis GM. 1988. The Stenothyridae of China. No. 2: Stenothyra hunanensis. Proc Acad Nat Sci Phila 140: 247-266.

Deap L, Degen P, van Zalinge N. 2003. Fishing Gears of the Cambodian Mekong. Phnom Penh, Cambodia: Inland Fisheries Research and Development Institute of Cambodia \& Mekong River Commission.

Froese R. 2006. Cube law, condition factor and weight-length relationships: history, meta-analysis and recommendations. $J$ Appl Ichthyol 22: 241-253.

Froese R., Pauly D. 2017. FishBase, World Wide Web electronic publication. Available at www.fishbase.org.

Gaspar M, Santos M, Vasconcelos P. 2001. Weight-length relationships of 25 bivalve species (Mollusca: Bivalva) from the Algarve coast (southern Portugal). J Marine Biol Assoc UK 81: 805-807.

Gayon J. 2000. History of the concept of allometry. Am Zool 40: $748-758$.

Glaubrecht M, Fehér Z, Rintelen von T. 2006. Brooding in Corbicula madagascariensis (Bivalvia, Corbiculidae) and the repeated evolution of viviparity in corbiculids. Zool Scr 35: 641-654.

Gutiérrez JL, Jones CG, Strayer DL, Iribarne OO. 2003. Mollusks as ecosystem engineers: the role of shell production in aquatic habitats. Oikos 101: 79-90. 
Halwart M. 2006. Biodiversity and nutrition in rice-based aquatic ecosystems. J Food Compost Anal 19: 747-751.

Hayes KA, Burks RL, Castro-Vazquez A, Darby PC, Heras H, Martín PR, Qiu J-W., Thiengo SC, Vega IA, Wada T, Yusa Y, Burela S, Cadierno MP, Cueto JA, Dellagnola FA, Dreon MS, Frassa MV, Giraud-Billoud M, Godoy MS, Ituarte S, Koch E, Matsukura K, Pasquevich MY, Rodriguez C, Saveanu L, Seuffert ME, Strong EE, Sun J, Tamburi NE, Tiecher MJ, Turner RL, Valentine-Darby PL, Cowie RH. 2015. Insights from an integrated view of the biology of apple snails (Caenogastropoda: Ampullariidae). Malacologia 58: 245-302.

Hecky RE, Kilham P. 1988. Nutrient limitation of phytoplankton in freshwater and marine environments: a review of recent evidence on the effects of enrichment. Limnol Oceanogr 33: 796-822.

Hilborn R, Waiters C. 1992. Managing fisheries. Quantitative Fisheries Stock Assessment: Choice, Dynamics and Uncertainty, London: Chapman \& Hall.

Hortle KG. 2007. Consumption and the yield of fish and other aquatic animals from the Lower Mekong Basin. MRC Technical Paper No. 16, Vientiane: Mekong River Commission.

Hortle KG, Troeung R, Lieng S. 2008. Yield and value of the wild fishery of rice fields in Battambang Province, near the Tonle Sap Lake, Cambodia. MRC Technical Paper No. 18, Vientiane: Mekong River Commission.

Huq KA, Hossain MI, Huda MN. 2002. Abundance and feeding ecology of freshwater apple Pila globosa (Swinson) in bell ecosystem of Gopalgonj. Univ $J$ Zool Rajshahi Univ 21: 35-36.

IUCN. 2013. Ecological Survey of the Mekong River between Louangphabang and Vientiane Cities, Lao PDR, 2011-2012 Vientiane, Lao PDR: IUCN, $241 \mathrm{p}$.

Köhler F, Seddon M, Bogan AE, Van Tu D, Sri-aroon P, Allen D. 2012. The status and distribution of freshwater molluscs of the Indo-Burma region. In: Allen D, Smith K, Darwall W, eds. The Status and Distribution of Freshwater Biodiversity in Indo- Burma. Cambridge: Gland, pp. 66-89.

Kummu M, Tes S, Yin S, Adamson P, Józsa J, Koponen J, Richey J, Sarkkula J. 2014. Water balance analysis for the Tonle Sap Lakefloodplain system. Hydrol Process 28: 1722-1733.

Lieng S, Yim C, van Zalinge N. 1995. Freshwater fisheries of Cambodia. I: the bagnet (Dai) fishery in the Tonle Sap River. Asian Fish Sci 8: 255-262.

Lim V. 1995. Summary of freshwater crustacea and mollusca in Cambodia, BSc thesis. Phnom Penh, Cambodia: Royal University of Agriculture (translated in English in 2003).

McCann KS, Gellner G, McMeans BC, Deenik T, Holtgrieve G, Rooney N, Hannah L, Cooperman M, Nam S, Giacomini H. 2016. Food webs and the sustainability of indiscriminate fisheries. Can J Fish Aquat Sci 73: 1-10.

Ministry of Agriculture Forestry and Fisheries [MAFF]. 2007. Declaration on Classification and List Wildlife Species. Phnom Penh: Ministry of Agriculture, Forestry \& Fisheries of Cambodia, pp. $1-39$.

MRC. 2003. State of the Basin Report 2003. Phnom Penh: Mekong River Commission.

MRC. 2010. State of the Basin Report 2010. Vientiane: Mekong River Commission.

MRC. 2011. Assessment of Basin-wide Development Scenarios: Cumulative Impact Assessment of the Riparian Countries' Water Resources Development Plans, Including Mainstream Dams and Diversions. Phnom Penh: Mekong River Commission.
Musig Y, Musig W, Satienjit S. 2012. Filtration rates of tropical freshwater bivalve mollusks: Pilsbryoconcha excilis compressa, Ensidens ingallsianus ingallsianus, Corbicula boudoni and Corbicula moreletiana. Kasetsart Univ Fish Res Bull 36: 23-29.

NCDD. 2010. Commune Database Online (CDBonline). National Committee for Sub-National Democratic Development. Available at http://db.ncdd.gov.kh/cdbonline/home/index.castle.

Ngor PB, Chhuon K, Prak LH. 2014. Cambodia launches pilot study to assess Tonle Sap mollusc fishery. Catch Culture 20: $8-13$.

Ngor PB, Chhuon K, Prak LH. 2016. Cambodia completes first pilot study of Tonle Sap mollusc fishery. Catch Culture 22: 4-13.

Ngor PB, Grenouillet G, Phem S, So N, Lek S. 2018a. Spatial and temporal variation in fish community structure and diversity in the largest tropical flood-pulse system of Southeast Asia. Ecol Freshw Fish 2018: 1-14.

Ngor PB, McCann KS, Grenouillet G, So N, McMeans BC, Fraser E, Lek S. 2018b. Evidence of indiscriminate fishing effects in one of the world's largest inland fisheries. Sci Rep 8: 8947.

NIS. 2013. Economic Census of Cambodia 2011: Provincial Report, 04 Kampong Chhnang Province. Phnom Penh: National Institute of Statistics, Ministry of Planning.

Persson L, Nang P, Ngin C, Pilgrim J, Sam C, Noel S. 2010. Ecosystem Services Supporting Livelihoods in Cambodia. Sweden: Stockholm Environment Institute.

Pigneur L-M, Falisse E, Roland K, Everbecq E, Deliège J-F, Smitz J, Van Doninck K, Descy J-P. 2014. Impact of invasive Asian clams, Corbicula spp., on a large river ecosystem. Freshw Biol 59: 573-583.

Poulsen AF, Ouch P, Viravong S, Suntornratana U, Nguyen TT. 2002. Fish Migrations of the Lower Mekong Basin: Implications for Development, Planning and Environmental Management. Phnom Penh: Mekong River Commission.

Poulsen AF, Hortle KG, Valbo-Jorgensen J, Chan S, Chhuon CK, Viravong S, Bouakhamvongsa K, Suntornratana U, Yoorong NTT, Tran BQ. 2004. Distribution and Ecology of Some Important Riverine Fish Species of the Mekong River Basin. Phnom Penh: Mekong River Commission.

Priawandiputra W, Nasution D, Prawasti T. 2017. Comparison of freshwater mollusc assemblages between dry and rainy season in Situ Gede System, Bogor, Indonesia. IOP Conf Ser Earth Environ Sci 58: 012007.

R Development Core Team. 2017. R: a language and environment for statistical computing. Vienna, Austria: R Foundation for Statistical Computing. Available at http://www.r-project.org.

Rainboth WJ. 1996. Fishes of the Cambodian Mekong. Rome: Food and Agriculture Organisation of the United Nations.

RUPP. 2010. Ecosystem Services Dependence, Rural Poverty and Population Movement in Battambangand Kampong Thom Provinces on the Tonle Sap Lake. Phnom Penh: Royal University of Phnom Penh.

Saleky D, Setyobudiandi I, Toha HA, Takdir M, Madduppa H. 2016. Length-weight relationship and population genetic of two marine gastropods species (Turbinidae: Turbo sparverius and Turbo bruneus) in the Bird Seascape Papua, Indonesia. Biodiversitas 17: 208-217.

Sangpradub N, Boonsoong B. 2006. Identification of Freshwater Invertebrates of the Mekong River and its Tributaries. Vientiane: Mekong River Commission.

Sarkkula J, Kiirikki M, Koponen J, Kummu M. 2003. Ecosystem processes of the Tonle Sap Lake. 1st Workshop of Ecotone Phase II, Phnom Penh, Cambodia. 
Sharma KK, Bangotra K, Saini M. 2013. Diversity and distribution of Mollusca in relation to the physico-chemical profile of Gho-Manhasan stream, Jammu (J\&K). Int J Biodivers Conserv 5: 240-249.

Simon KD, De M, Mazlan AG. 2014. Length-weight relationship and trophic level of hard-tail scad Megalaspis cordyla. ScienceAsia 40: $317-322$.

Sodhi NS, Koh LP, Brook BW, Ng PKL. 2004. Southeast Asian biodiversity: an impending disaster. Trends Ecol Evol 19: 654-660.

Sor R, Boets P, Chea R, Goethals P, Lek S. 2017. Spatial organization of macroinvertebrate assemblages in the Lower Mekong Basin. Limnologica 64: 20-30.

Sousa R, Antunes C, Guilhermino L. 2008. Ecology of the invasive Asian clam Corbicula fluminea (Müller, 1774) in aquatic ecosystems: an overview. Ann Limnol - Int J Lim 44: 85-94.

Statzner B, Higler B. 1985. Questions and comments on the River Continuum Concept. Can J Fish Aquat Sci 42: 1038-1044.
Strong EE, Gargominy O, Ponder WF, Bouchet P. 2008. Global diversity of gastropods (Gastropoda; Mollusca) in freshwater. Hydrobiologia 595: 149-166.

Vanderploeg HA, Liebig JR, Nalepa TF. 1995. From picoplankton to microplankton: temperature-driven filtration by the unionid bivalve Lampsilis radiata siliquoidea in Lake St. Clair. Can J Fish Aquat Sci 52: 63-74.

Vannote RL, Minshall GW, Cummins KW, Sedell JR, Cushing CE. 1980. The River Continuum Concept. Can J Fish Aquat Sci 37: $130-137$.

Vaughn CC, Hakenkamp C. 2001. The functional role of burrowing bivalves in freshwater ecosystems. Freshw Biol 46: 1431-1446.

Vaughn CC, Nichols SJ, Spooner DE. 2008. Community and foodweb ecology of freshwater mussels. J North Am Benthol Soc 27: 409423.

Zhou D. 2002. The Customs of Cambodia. M. Smithies, Bangkok: Siam Society, first translated from Chinese into French by Paul Petillot and published in 1902.

Cite this article as: Ngor PB, Sor R, Prak LH, So N, Hogan ZS, Lek S. 2018. Mollusc fisheries and length-weight relationship in Tonle Sap flood pulse system, Cambodia. Ann. Limnol. - Int. J. Lim. 54: 34 